\title{
CHEMISTRY ICT AND LABORATORY EQUIPMENT MANIPULATIVE SKILL TRAINING FOR CHEMISTRY TEACHERS IN EAST AGAM
}

\author{
Miftahul Khair ${ }^{1}$, Budhi Oktavia ${ }^{1}$, Guspatni ${ }^{1}$, Tarmizi ${ }^{1}$ \\ 1. Chemistry Department, State University of Padang \\ Korespondensi: Jl. Prof. Dr. Hamka Air Tawar, Padang, Sumatera Barat, Indonesia \\ (miftah/budhiokt/patni/tarmizi)@fmipa.unp.ac.id
}

\begin{abstract}
In general, schools in eastern Agam Regency have not yet making use optimal computer technology in learning process. Furthermore, limited innovation has been made dealing with the limitation of chemical laboratory work materials. To answer the problem, training on making use of ICT in Chemistry subject and manipulative skill laboratory equipments for Chemistry teachers throughout eastern Agam Regency was conducted.
\end{abstract}

Kata kunci: ICT, manipulative skill, laboratory

\section{INTRODUCTION}

$\mathrm{G}$ enerally, schools in eastern Agam do not optimally utilize computer technology in learning process. This can be seen from the use of instructional media which is still far from the latest technology. The method applied by chemistry teachers and lecturers still relies on the blackboards to explain the various theories and practices of chemistry.

Conversely, the availability of facilities, such as computer labs, internet connection, LCD projector and also other media, are very supportive to the implementation of computer assisted learning, currently known as the Computer Assisted Instruction (CAI). It is unfortunate if the availability of such facilities could not be used well by chemistry teachers for teaching chemistry. In addition, chemical lab equipments which are expensive in term of cost are often constrained to be implemented properly. Here, the role of ICT is needed to replace the laboratory practices.

Chemistry Laboratories at the schools of interest in the project site are still less in terms of quantity and quality of tools and materials. Indeed, the limited number of tools and chemicals can actually be overcome by manipulating engineering skill by using tools that are available all around us. Chemicals can be replaced by inexpensive natural ingredients also available numerously in our environment.

Due to the less skilled teachers in East Agam district in using Chemistry ICT and laboratory equipment manipulation tools. Learning Chemistry is still done conventionally, i.e. classically and minimally laboratory practice. There should be a training for them in order to increase knowledge and skills about Chemistry ICT and Laboratory Manipulative Skill.

This project is primarily intended for chemistry teachers, especially high 
school chemistry teachers in East Agam. Activities were conducted in the form of ICT training, such as using MS Power Point, MS Word, MS Excel, and Molecular Structure drawing Softwares. We have taught tips in making simple distillation equipments, manipulating surrounding tools into tools of laboratory, harnessing environment and utilizing plants as acid-base indicators etc.

Based on the problems mentioned above, the purpose of this project are Providing ICT skills in the field of chemistry such as: MS Power Point, MS Word, MS Excel, and ChemOffice and Improving the chemical knowledge so that teachers can take advantage of the surrounding tools and natural materials for chemistry experiments.

There are some benefits expected, namely, participants would be accustomed to using computers and internet facilities available for creating instructional media, participants can use the skills given to manipulate the chemistry lab equipment in order to get around the limited tools and laboratory materials, participants can save the cost of purchasing tools and materials for teaching and chemistry laboratory and the participants can disseminate the knowledge and skills gained to other teachers and school students concerned.

\section{OBJECTIVE}

Problematic of education nowadays is still struggling between the equity and way to increase access of education for all. Recent world community begins applying ICT (Information and Communication of Technology) into all sectors of life integrally. Indonesia as part of the global community should actively participate in this race which we can see with the start of some sectors of national life that began to exploit the existence of ICT especially in the educational sector.
'School' is an organization which continually carries out formal education often referred as 'PBM' (LearningTeaching Activities). To improve the quality of education and access to it one strategy that began to do was the holding of a learning system that utilizes ICT, whether it is e-Learning, Distance Learning, Distance Education, Computer Based Training, Computer Assistance Instruction, Computer Based Instruction, Cybernetic Learning Environment, Desktop Videoconferencing, Integrated Learning Center, Learner-Centered Classroom, teleconferencing, Web-Based Training or others.

CAI (Computer Assistance Instruction) is one of the applications of ICT in the education system, particularly in facilitating the implementation of teaching and learning activities. Through CAI teachers are always able to ensure their participation in the guidance of student study activities either at home or in the classroom in the context of the subject matter more than existing classroom learning. The students are conditioned to be more enthusiastic about learning via CAI materials and can easily take advantage and relax in repetition of the discussion to deepen the course materials.

In addition, CAI can be used as reliable as a teaching assistant. It can have more content that gives a chance to mediate the skills and motor skills (application of learning materials) in addition to understanding the subject matter being taught.

Information technology is a new force emerging in the 21 st century with the main characteristics of information technology development very rapid, both in terms of infrastructure, facilities, information technology infrastructure, hardware, and software. Who controls this new weapon, he/she will become the ruler of information (Adri, 2008). 
System is a network of procedures that are interconnected, gathered together to perform an activity or to accomplish a particular goal (Fitz Gerald 1981) in (Jogiyanto, 1989). According to Steven Alter, Information System is the group's system of components, functions, objects procedures, etc, interacting each other to gain predefined common goals (Alter, 2002).

One area that was touched in the development of this technology is the world of education. Use of MS Office and chemical softwares grows very rapidly. These are the helpful teachers in the learning process of chemistry. Microsoft Office such as MS Word, MS Excel, MS Power Point is the software that is very often used in daily situations. However it is not still optimally used in the learning process.

Microsoft Word (MS Word) is a word processing program widely used nowadays compared to other word processing programs, such as WordStar, AmiPro, WordPerfect and others. This factor is influenced by the facilities provided, ease of use, the results obtained, an attractive appearance and many others. Microsoft Word has the ability to create tables, insert other program to program and other facilities.

Microsoft PowerPoint is a program for computer presentations developed by Microsoft. PowerPoint is widely used, especially by the office and businesspeople, educators, students, and trainers.

Computational chemistry is a branch of chemistry that uses the results of theoretical chemistry that is translated into a computer program to calculate properties of molecules and the changes and perform simulations on large systems (macromolecules such as proteins or many molecular systems such as gas, liquid, solid, and liquid crystal), and to implement the program in real chemical systems.
Manipulating laboratory equipments is intended to provide laboratory equipments cheaply and easily made by teachers. This may provide motivation and inspiration to teachers or laboratory technician to be able to modify laboratory equipments from used materials. In addition, manipulation can overcome the deficiencies or to make tools that are not yet available in the laboratory by the teachers (Tarmizi, 2009).

\section{METHOD}

\section{Preparation}

We conducted several meetings with representative of teachers as informants and participants to formulate steps in the implementation of these training programs, particularly those to set the schedules, to determine the division of tasks and training materials. The purpose of this meeting and the discussion is in order to stabilize the plan and look for new suggestion related with the programs to be implemented. We made agreement with the host school at which the training programs will be conducted.

\section{Implementation}

The next activity was to invite the participants, making schedule of activities and places at which the project will be implemented. Those who were invited as participants in this project are all upper secondary schools (including Islamic boarding schools) that have chemistry teachers. By considering effectiveness of training, participants was only limited to 20 people and each school is limited to only send one chemistry teacher. The project was then conducted on Thursday and Friday, December 24-25 December 2009 and housed at the Computer Lab of SMAN 1 Kamang Magek, Agam. 


\section{Training Topics}

Topics trained are MS Word for Chemistry and Scientific Work, MS Excel for Chemistry, MS Power Point as Teaching Media in chemistry, Chem Office for drawing chemical structures (Baaden, 2000), and manipulative skill of laboratory equipments.

\section{Tools and Materials:}

Computers, laptops, LCD projectors, student made funnel statives, student made distillation tools, dilute $\mathrm{HCl}$, dilute $\mathrm{NaOH}$, pp indicators, Litmus papers, turmeric, Bougenvile flower with many colors, Senduduk flower, and carrots.

\section{The method used}

These training activities are conducted in two parts; Chemistry ICT training and Workshop / practice of chemistry laboratory equipment manipulative skills.

\section{RESULTS AND DISCUSSION}

\section{In-situ Process Result}

In this training we have seen some results that can be observed during the process of training activities, namely: interest and seriousness of the participants in attending the activities of training programs and the participants skills in computer usage and utilization of natural materials for chemistry experiments.

Based on observations during the training activities, it was observed the lack of interest from teachers invited to be participants, i.e only $55 \%$ of the participants who came from 20 schools which were invited. Nevertheless, the participants who followed had passion and commitment during training, and they were generally able to understand all materials given. This is seen in $100 \%$ of the participants' presence at the first and second day. Similarly, there are participants who requested the trainer team to hold a similar event on the forum MGMP/ (Musyawarah Guru Mata Pelajaran) in the future.

\section{Result as Achievement of Goals}

a. Through this training, teachers are expected to be able to teach the knowledge and skills gained to colleagues in school.

b. Through this training, teachers are expected to be able to teach the knowledge and skills acquired to the students and the school computer laboratory technicians.

c. Through this training, participants are also expected to be able to apply knowledge acquired in training project and not just referring to mere theory.

d. Through this program, teachers are expected to be more creative in making use of natural materials available around them to be chemical lab tools. They should not depend on chemical suppliers and Government funds (Diknas) anymore.

e. This program can also be used as models in the business development of ICT-based skills and creative skills that can be developed in schools.

In assessing whether the participants are enthusiastic and highly motivated after the training, result indicators shows that apparently a lot of questions arised during the training given. Training could bring awareness to the participants that the use of ICT can ease the process of study and chemistry labwork. Participants then apparently know that the chemistry laboratory can be accomplished with natural chemicals that are available daily, and last but not the least, there was requests from participants in order to hold again this project next time in the same with longer time (in the 
forum of MGMP/ Musyawarah Guru Mata Pelajaran).

There are several inhibiting factors found in the conduct of this program i.e. the limited time available, so that the material presented was not too deep, the participants did not have much time to catch the material quickly, and the weather was not so good so that many participants could not attend.

Supporting factors encountered in implementing this program were the presence of attention and active participation of school boards, good response during training of teachers, the availability of ICT devices and the last but not the least participants also have had own personal computers / laptops.

\section{Relevance}

The program is to foster a creative attitude of the participants, so hopefully after the completion of this training the teachers can apply the knowledge and skills acquired during training activities in the learning process in schools. In addition it will reduce operating costs in the school chemistry lab project. The procurement program is very relevant because the schools already have computer labs.

\section{Response}

There was good response from teachers, especially chemistry teachers who attended against the procurement and execution of this training program. Host principal provided significant motivation for her members in speech at the opening of the training. With the support and motivation of school leaders, the event run smoothly and provided participants with serious skills.

\section{Accuracy}

Selection of ICT training materials and skills to manipulate tools for chemistry teachers was very fine, because teachers are parties that determine the success of the education at the schools. The ability of teachers in presenting the material, classroom management, and empowering the students needs creative teachers to get good results. Teachers must have the knowledge, abilities and skills in selecting and applying the learning model that can increase the interest of other community members to a lesson. By this project, we believe that every trainee has been able to implement new learning strategies which provide applied chemistry skills, so that other teachers become skilled. Thus the main target of manipulation skills training and laboratory equipments provided is achieved.

\section{Long-Term Impact}

It should be able to enhance the learning process more effectively and posses better manipulation skills.

\section{CONCLUSION AND SUGGESTION}

To improve the quality of the learning process of chemistry and chemistry labwork at Senior High Schools at Eastern Agam, we had provided knowledge and skills in the use of ICT and Laboratory equipments Manipulative Skills. In this training it was seen some results that could be observed during the process of training, namely: interest and seriousness of the participants in following the activities of this training program, skills of participants in each training materials, the number of participants expected to be the cadres for the continuation of this program. The selection of representative materials for teachers is appropriate because the members of this group can be expected to share their knowledge to the relevant parties in schools.

Presumably there should be monitoring of the weaknesses and teachers' success in applying knowledge and skills 
they already acquire. Monitoring is not only intended as a preparation for evaluation of community service programs, but also as an academic research activity. This project can be done at other schools

\section{REFERENCES}

Adri, M. 2008. Guru Go Blog. Jakarta, PT Elex Media Komputindo.

Alter, S. 2002. Information Systems: Foundation of E-Business. San Francisco, Prentice Hall.

Baaden, M. 2000. Molecular Modeling with the ChemOffice Ultra 4.5 Program Suite. Cambridge, in West Sumatra, especially those that are still less skilled in Chemistry ICT and manipulation skill, but they already have computer laboratory facilities.

Jogiyanto 1989. Analisis dan Desain Sistem Informasi. Yogyakarta., Andi.

Tarmizi 2009. Manajemen Laboratorium. Padang, UNP Press. 